\title{
Establishment of Morphogenic and Regeneration Ability in two Indica Rice Cell Suspension Cultures after Exposure to $\mathrm{NaCl}$
}

\author{
T.L. Aditya* \\ Department of Agriculture, Imperial College at Wye, University of London, TN25 5AH
}

Key words: Indica rice, Cell suspension, Morphogenic, Regeneration

\begin{abstract}
An efficient protocol was developed for in vitro morphogenic ability along with plantlet regeneration of two Bangladeshi indica rice varieties (BR24 and BR26) via somatic embryogenesis by applying $50 \mathrm{mM} \mathrm{NaCl}$ stress in callus induction and suspension initiation media. Osmotic stress was induced by $\mathrm{NaCl}(50,100,150$, 200 and $250 \mathrm{mM}$ ) on the cell growth in suspension maintenance media. In viability test stress adapted cells showed $85-95 \%$ viability up to $200 \mathrm{mM} \mathrm{NaCl}$ compared with stress shocked (MS1-50) and control (MS1-0) treatments. Higher stress adapted cells showed growth retardation and the induction of plasmolysis. For both genotypes somatic embryos were obtained in both MS based liquid and semisolid media with or without 50 and $100 \mathrm{mM} \mathrm{NaCl}$. Cell suspension-derived micro-calli were partially desiccated $(6-12 \mathrm{hr})$ and subsequently maintained in MS1 callus induction media supplemented with proline (12 mM), ABA (2 mg/l) and $0.6 \%$ phytagel in the presence or absence of 50 and $100 \mathrm{mM} \mathrm{NaCl}$. Subsequently, desiccated somatic embryos were transferred in MS based regeneration media with or without 50 and $100 \mathrm{mM} \mathrm{NaCl}$. Proline mediated callus was found to be more effective in embryo differentiation than ABA. Partial desiccation dramatically enhanced callus growth and partially increased regeneration percentage. BR24 showed a better regeneration response producing plantlets in presence of proline in control media while BR26 restored regeneration potential in the presence of $\mathrm{ABA}$ and $100 \mathrm{mM} \mathrm{NaCl}$. Plantlets regenerated from salt stressed callus cultures were then grown in compost in a glasshouse and produced normal, fertile plants.
\end{abstract}

\section{Introduction}

In suspension cultures, cells and embryos are exposed to nutrients, growth regulators etc. in which the media components can be controlled precisely to induce development of somatic embryos in a uniform manner. The significant feature of embryogenic rice cell suspension is that these are largely composed of

*Division of Plant Breeding, Bangladesh Rice Research Institute, Gazipur-1701, Bangladesh. $<$ tamaladitya@yahoo.com>. 
embryogenic cells compared with other explant or callus cultures (Jain et al. 1997). Embryogenic cell suspensions have proven best for protoplast studies and are preferred for genetic transformation studies related to DNA uptake by protoplasts.

The morphogenic capacity of indica rice cell suspensions was observed by inoculating suspension on MS based solid medium (MS + $2.5 \mathrm{mg} / \mathrm{l} 2,4-\mathrm{D}$ ) as reported by Valdez et al. (1997). They found undifferentiated microcalli one month after culture. There are several reports of successful in vitro somatic embryogenesis via cell suspension culture of indica rice (Rani and Reddy 1996, Tsukahara et al. 1996) although successful embryogenesis occurred rather sporadically and transiently in some cases. Japonica rice cultivar retained its regeneration potential after exposure to $\mathrm{NaCl}$ in cell suspension maintenance media followed by regeneration media (Binh et al. 1992). In contrast, Indica rice cultivars display lower rates of plant regeneration through callus and cell suspension culture than japonica cultivars (Abe and Futsuhara 1991). A number of factors such as genotype (Abe and Futsuhara 1991), development stage of cells in the explants (Mariani et al. 2000), hormonal composition of the medium (Khana and Raina 1998), carbohydrate source (Navraj-Kaur et al. 1999, Pandey and Bhojwani 1999) and water stress or partial desiccation treatments (Jain et al. 1996) have been examined to improve the frequency of somatic embryogenesis and plant regeneration in both callus and suspension cultures of rice.

This study involved the use of $\mathrm{NaCl}$ in restoration of the regeneration potential of embryogenic calli, derived from pre-treated suspension cultures. To investigate osmotic stress-induced morphogenic changes and to elucidate adaptive mechanisms at the cellular level, high concentrations of $\mathrm{NaCl}$ ( 200 and $250 \mathrm{mM}$ ) were employed. The objectives of this study were to determine the morphogenic and regeneration ability of two Bangladeshi indica rice cultivars via embryogenic cell suspension cultures derived from $\mathrm{NaCl}$ stress-adapted treatments.

\section{Materials and Methods}

The two Bangladeshi modern indica rice varieties, namely BR24 and BR26 were selected for this study on the basis of friable, soft and embryogenic callus induction ability.

Four to eight weeks old embryogenic seed-derived calli (small, globular, softfriable) were transferred to either $100 \mathrm{ml}$ Erlenmeyer flasks containing $10 \mathrm{ml}$ or 5 $\mathrm{cm}$ Petri dishes containing $5 \mathrm{ml}$ MS liquid media modified by $1 \mathrm{mg} / 1$ 2,4-D, 0.5 $\mathrm{mg} / \mathrm{l} \mathrm{Kn}$ and $20 \mathrm{~g} / \mathrm{l}$ sucrose. The cultures were placed on a gyratory shaker at 80 $100 \mathrm{rpm}$ and incubated under $16 \mathrm{hr}$ photoperiod at a light intensity of 55 $\mu \mathrm{mol} / \mathrm{m}^{2} / \mathrm{s}$. Three weeks after initiation of culture the resulting suspensions of 
cells were subcultured by addition of fresh media of the same original constitution at a dilution ratio of $1: 1$ every seven-ten days. Two types of cell suspension cultures were initially developed and maintained. The first type was cells initially developed and maintained in MS1 control medium and referred to as normal cells. The second type was cells initially developed and maintained in the same MS1 but supplemented with $50 \mathrm{mM} \mathrm{NaCl}$ and referred to as stressed cells. To produce finely divided uniform suspension cultures, even cell sizes were regulated by pipetting-off (sterile fine glass pasteur pipette) during each subculture period. Finely divided stressed cell suspension cultures were used for osmotic stress-adapted treatments. MS1 supplemented with $\mathrm{NaCl}$ at 100, 150, 200 and $250 \mathrm{mM}$ was introduced over a period of 16 days in a step-wise manner. For this purpose aliquots of $5 \mathrm{ml}$ stressed cells were spun down at 500 - $650 \mathrm{rpm}$ for 7 min in a graduated sterile centrifuge tube $(0.1 \mathrm{ml}$ scale). Cell pellets were resuspended in $5 \mathrm{ml}$ stress-adapted treatments at an initial density of $1-1.5 \times$ $10^{4}-105 / \mathrm{ml}$ in $5 \mathrm{~cm}$ diameter Petri dishes. Three Petri dishes were used for each treatment. Cell viabilities were assessed at four days intervals over a 16-dayperiod on stress adapted treatments.

Growth rate of the cell lines was determined by the difference between initial cell counting and counting after a period of time intervals. The cells/aggregates density was adjusted using a haemocytometer and viewed under an Olympus IMT2 inverted compound microscope. Cells were counted from three out of 16 chambers whose volume was known to provide an estimated density per $\mathrm{ml}$ in a sample of cell suspension.

Prior to each subculture the percentage of cell viability was determined using FDA staining (Widholm 1972). Equal volumes of cell suspension and FDA solution $(0.5 \mathrm{ml}$ of FDA stock solution ( $3 \mathrm{mg} / \mathrm{ml}$ acetone) diluted in $10 \mathrm{ml}$ cell suspension media) were mixed and allowed to settle for five min at room temperature. After five min of incubation, samples were viewed under UV light (with a blue filter) using an Olympus IMT2 inverted compound microscope. Viable cells were indicated by a green-yellow fluorescence and viability defined as the percentage of fluorescing cells. After osmotic shock treatment cell suspension viability was also determined using the same procedure. Three samples from each dish were assessed on viability and the mean values obtained from three replicated dishes used for statistical comparison.

Packed cell volume (PCV) is one of the measurements of cell growth in cell suspension cultures typically expressed as a percentage of the total volume in the tube. The PCV values for each culture type were determined two weeks after stress-adapted treatments. Five $\mathrm{ml}$ suspension cultures were spun down at 800 rpm for seven min in a graduated centrifuge tube $(0.1 \mathrm{ml}$ scale). Data were collected from three Petri dishes for individual treatments. Growth of cell 
suspensions was represented by plotting the means of PCV of $5 \mathrm{ml}$ inocula against the stress-adapted treatments.

The morphogenic capacity of these suspensions was investigated by inoculating $1 \mathrm{ml}$ of suspension (at a density of $1-2 \times 10^{3}-0.5-1 \times 10^{4}$ cells/ aggregates per $\mathrm{ml}$ ) in $4 \mathrm{ml}$ MS1 liquid media or on $25-28 \mathrm{ml}$ MS1 solid media in the presence or absence of 50 and $100 \mathrm{mM} \mathrm{NaCl}$ for a period of four - six weeks. Microcalluses started to become visible two weeks after culture and produced undifferentiated primary calluses $(1 \mathrm{~mm}-0.4 \mathrm{~cm})$ after a month of culture. Data were recorded as the number of microcalluses per Petri dish. For each treatment combination (genotype $\times$ media) three Petri dishes were represented as three replications.

Glutinous, soft, pale yellow, watery and loosely packed microcalli produced from suspension cultures were cultured on MS1 callus induction media. Two weeks after culture, the soft secondary calli were partially desiccated on two layers of sterilized Whatmann $3 \mathrm{MM}$ papers in $5 \mathrm{~cm}$ diam. Petri dishes. The dishes were sealed with parafilm and kept at $25^{\circ} \mathrm{C}$ in the dark for $6-12 \mathrm{hr}$. Subsequently, about $0.01-0.05 \mathrm{~g}$ of partially desiccated calli were cultured on six different types of media supplemented with $12 \mathrm{mM}$ proline or $2 \mathrm{mg} / \mathrm{l} \mathrm{ABA}$ in presence or absence of 50 and $100 \mathrm{mM} \mathrm{NaCl}$. To increase the stress condition, the concentration of gelling agent (phytagel) in MS1 callus induction media was also increased from 0.3 to $0.6 \%$. Three replicated dishes were used for each treatment combination (genotype $\times$ media). The dishes were incubated at $25^{\circ} \mathrm{C}$ in the dark. Callus growth was indicated by taking fresh weight ten days after culture and percentage weight gain calculated.

For regeneration of plantlets, the resultant calli from each conditioned media were transferred to four different types of regeneration media designated as A - 0 (MS1 + $2 \mathrm{mg} / \mathrm{l} \mathrm{BAP}+1 \mathrm{mg} / \mathrm{l} \mathrm{Kn}+0.5 \mathrm{mg} / \mathrm{l} \mathrm{NAA}+0.3 \%$ phytagel), $\mathrm{A}-50$ (MS1 + 2 $\mathrm{mg} / \mathrm{l} \mathrm{BAP}+1 \mathrm{mg} / \mathrm{l} \mathrm{Kn}+0.5 \mathrm{mg} / \mathrm{l} \mathrm{NAA}+0.3 \%$ phytagel $+50 \mathrm{mM} \mathrm{NaCl}), \mathrm{B}-0$ (MS1 $+1 \mathrm{mg} / \mathrm{l} \mathrm{BAP}+2 \mathrm{mg} / 12 \mathrm{iP}+0.2 \mathrm{mg} / 1 \mathrm{NAA}+0.4 \%$ phytagel) and B -50 (MS1 + 1 $\mathrm{mg} / \mathrm{l} \mathrm{BAP}+2 \mathrm{mg} / \mathrm{l} 2 \mathrm{iP}+0.2 \mathrm{mg} / \mathrm{l} \mathrm{NAA}+0.4 \%$ phytagel $+50 \mathrm{mM} \mathrm{NaCl})$. The cultures were incubated at $25^{\circ} \mathrm{C}$ at $16 \mathrm{hr}$ photoperiod for another four - six weeks. The regeneration frequency (Rf) was calculated and the average number of plantlets per callus $\left(\mathrm{Pl}_{\mathrm{pc}}\right)$ were counted.

Data were analysed using two-way or, occasionally, one-way ANOVA through Genstat 4.1 Windows Computing Programme.

\section{Results and Discussion}

During the suspension initiation period growth of cells/cell clusters was determined by counting the number of cells and cell clusters over 21 days at four day intervals from culture initiation. Relatively high numbers of cells and cell 
clusters per $\mathrm{ml}$ were observed for genotype BR24 in both treatments (MS1-0 and MS1-50) at days four and eight (Fig. 1a, b). Genotype BR26 performed similarly in both control and stressed treatments (Fig. 1a, b). In general most friable and nodular calli gave rise to suspension cultures with the greatest degree of cell dispersion in AA and MS based media as demonstrated by other workers (Redway et al. 1990, Ghosh and Zapata 1992). Ozawa et al. (1996) reported that embryogenesis also occurred at high frequency from relatively small clusters of cells in liquid media. The present study supports these views with cell suspension cultures of these two genotypes composed mainly of a large number of single cells and relatively smaller clusters.
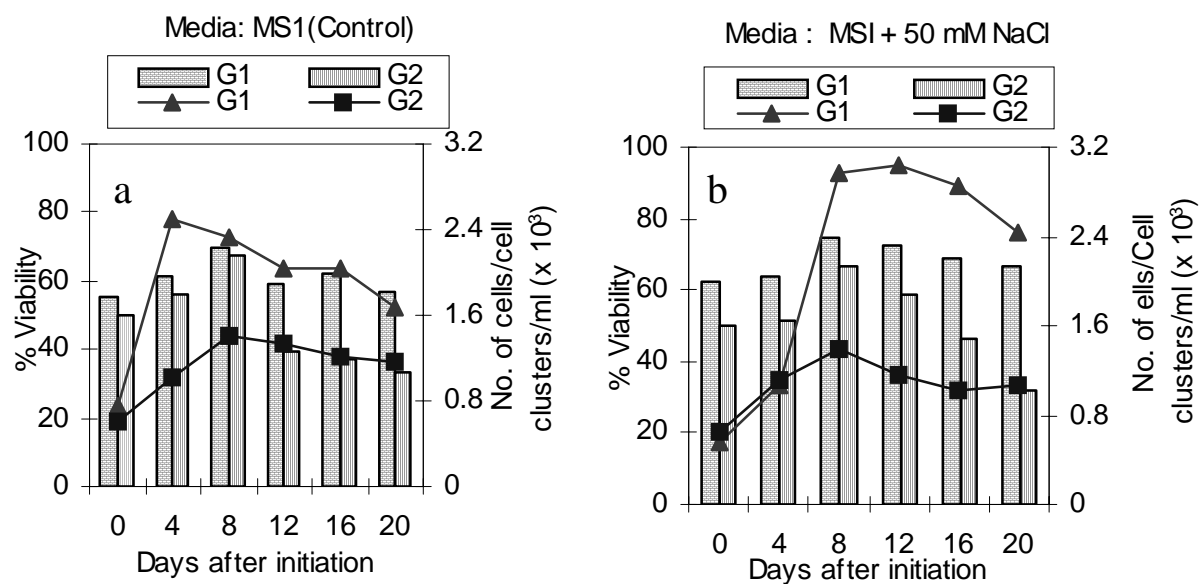

Fig. 1(a-b). Effect of culture media and genotype on the growth of cells/cell clusters and viability at different time periods from culture initiation. Line graph represent the number of cells/cell clusters while bar graph represent percentage viability. G1 = BR 24 and G2 = BR 26.

During the culture initiation period, cell viability was measured over a period of 20 days at four-day intervals. The highest viability was observed in media MS1-50 for genotype BR24 at day eight followed by days 12, 16 and 20 while BR26 showed the highest viability at day eight in both treatments followed by day 12 in media MS1-50 (Fig. 1b). Viability gradually decreased eight days after culture for both genotypes except at day 16 when viability slightly increased from day 12 for BR24 in control media.

Changes in viability in two indica rice genotypes were observed with FDA staining after stress-adapted treatments with different levels of $\mathrm{NaCl}$ over 16 days at four day intervals. $\mathrm{NaCl}$ was introduced at 100, 150, 200 and $250 \mathrm{mM}$ to $50 \mathrm{mM} \mathrm{NaCl}$ stressed suspensions of two genotypes. At day 0 BR 24 gave the highest viability at $150 \mathrm{mM} \mathrm{NaCl}$ while BR26 gave the highest viability at 200 $\mathrm{mM} \mathrm{NaCl}$ (Fig. 2a). Increasing the time period from the initial stress adaptation stage resulted in changes of viability for both genotypes. Viability significantly decreased from $100 \mathrm{mM} \mathrm{NaCl}$ to 150, 200 and $250 \mathrm{mM} \mathrm{NaCl}$ for BR24. Significant 
differences between the two genotypes at $250 \mathrm{mM} \mathrm{NaCl}$ were observed at day four. In contrast, viability increased from $100 \mathrm{mM} \mathrm{NaCl}$ to $150 \mathrm{mM} \mathrm{NaCl}$ for genotype BR26. At days four, eight, 12 and 16, BR26 gave the highest viability at $150 \mathrm{mM} \mathrm{NaCl}$ (Fig. 2 (b-e). At days 12 and 16 viability decreased at 200, 250 and $300 \mathrm{mM} \mathrm{NaCl}$ for both genotypes (Fig. 2e). Hosseini and Mulligan (2002) studied the cell death pathways in cell suspension cultures of Oryza sativa rice cv. Taipei 309 and found single strand-preferring nucleases (SSPNs) activity was strongly inhibited by $10 \mathrm{mM}$ EDTA and EGTA resulted in concomitant loss of cell viability. In the present study cells died due to the inhibition of increased level of $\mathrm{NaCl}$ and showed loss of cell viability which is consistent with reported study.

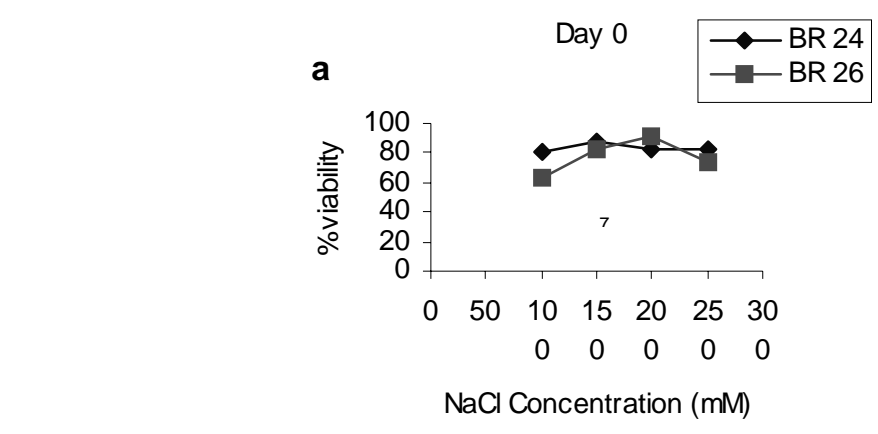

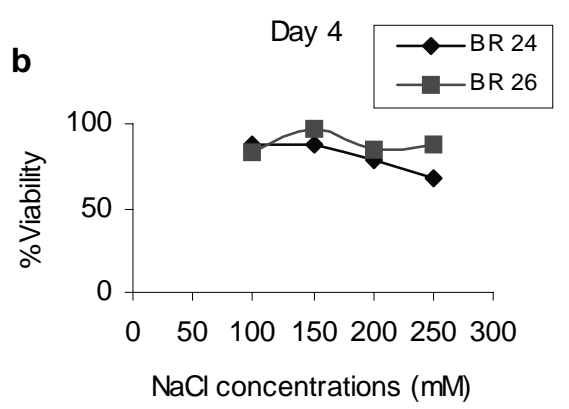

d

Day 12

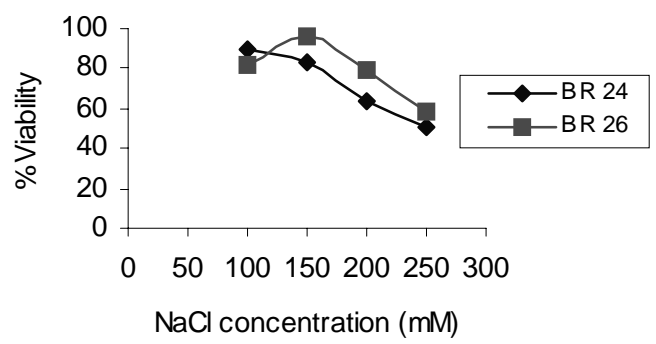

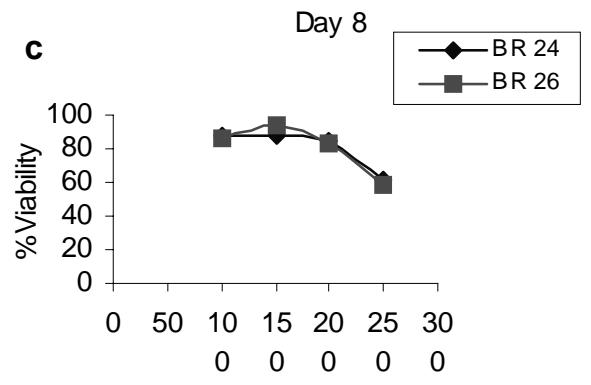

$\mathrm{NaCl}$ concentrations $(\mathrm{mM})$

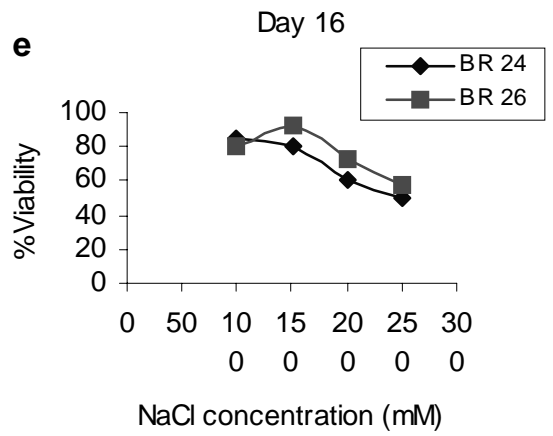

Fig. 2 (a-e). Changes in viability of two indica rice genotypes after sress adaptation treatments with different concentrations of $\mathrm{NaCl}$ for different time periods. 
In stress-adapted treatments cell growth was measured as packed cell volume (PCV) at the end of each stress-adapted treatment $(100-250 \mathrm{mM} \mathrm{NaCl})$. For the both genotypes optimum cell growth was observed after 100 and $150 \mathrm{mM}$ stress. The cell growth was decreased with the increasing level of stress treatments for both genotypes (Fig. 3). A two-sample t-test detected no significant differences between the two genotypes at each concentration tested (Fig. 3). Bahaji et al. (2003) reported that when rice cells were subjected to saline or osmotic stress there was an initial dose-dependent inhibition of uptake. They reported that the inhibition of growth commonly caused by different stress agents used in this study which is supported to the present study. The stressadapted cells had a normal cell size and viability in $\mathrm{NaCl}$ induced suspensions although high osmotic shock $(250 \mathrm{mM} \mathrm{NaCl})$ caused plasmolysis and decreased cell viability. Lee et el (2004) found rapidly proliferating cells with reduced cell aggregation of four japonica and one indica cultivars in AA medium supplemented with $2 \mathrm{~g} / \mathrm{l}$ casein enzymatic hydrolysate and same media supplemented with $0.005 \%$ pectinase. This study revealed that the degree of rapidly growing proliferated cells in suspension culture was genotype dependent which was also found in the present study.

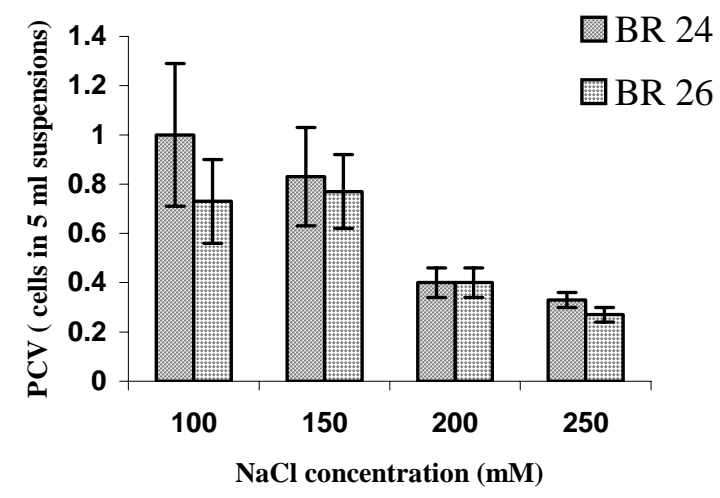

Fig. 3. Changes in cell growth as a packed cell volume after stress adapted treatment with different concentration of $\mathrm{NaCl} . \mathrm{p}=0.45,0.81,1.0$ and 0.23 for 100, 150, 200 and $250 \mathrm{mM} \mathrm{NaCl}$ concentrations while $t=0.79,0.27,0.00$ and 1.41 for 100, 150, 200 and $250 \mathrm{mM} \mathrm{NaCl}$, respectively. Bars represent SEM.

Established fine embryogenic cell suspensions were subcultured in MS1 liquid media with or without 50 and $100 \mathrm{mM} \mathrm{NaCl}$ (Fig. 4A). The highest number of microcalli was observed for BR26 four weeks after culturing in control medium followed by media with $50 \mathrm{mM} \mathrm{NaCl}$ (Fig. 4B). Genotype BR24 performed lower microcalli formation compared with BR26 (Table 1). There was no significant interaction between genotype and concentration on the formation of microcalli. Morphogenic calli were also produced on MS basal semi-solid callus induction media with or without 50 and $100 \mathrm{mM} \mathrm{NaCl}$. The highest 
number of microcalli was produced on MS1 control media for BR24 followed by the same media with $100 \mathrm{mM} \mathrm{NaCl}$ (Fig. 4C). Jain et al. (1996) reported the morphogenic potential of cell-suspension derived calli of indica and Japonica rice varieties. These calli regenerated shoots and best regeneration frequencies were obtained when $24 \mathrm{hr}$-desiccated calli were grown on MS based regeneration media with $1.0 \%(\mathrm{w} / \mathrm{v})$ agarose. This study indicates the osmotic stress induced by agarose had a stimulatory effect on regeneration potential which partially supports the present study because morphogenic rice calli derived from $100 \mathrm{mM}$ stress adapted treatment showed embryogenic response.
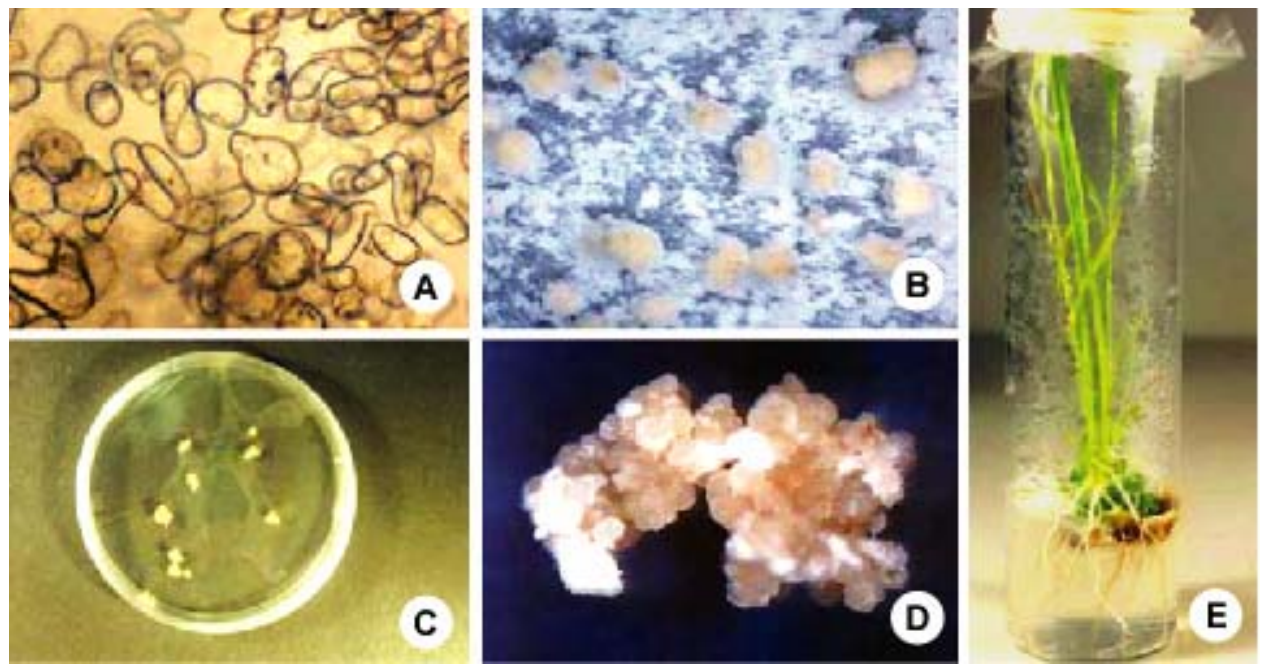

Fig. 4(A-E). Embryogenic cell suspension of indica rice genotype in modified MS media (A: $\times 500)$ De-differentiation of somatic embryos or microcalli in MS basal liquid (B: $\times 500)$ and solid media $(\mathrm{C}: \times 500)$ in the presence of $100 \mathrm{mM} \mathrm{NaCl}$, respectively. Formation of secondary calli obtained from partially desiccated microcalli and supplemented with $2 \mathrm{mg} / \mathrm{l} \mathrm{ABA}(\mathrm{D}: \times 500)$ in the presence of $50 \mathrm{mM} \mathrm{NaCl}$. Plantlet formation (E) from $50 \mathrm{mM}$ salt-stressed somatic embryos on MS based control regeneration media.

Primary micro-calli were subcultured on semi-solid maintenance media after partial desiccation treatment. Secondary globular, nodular, whitish or yellowish calli were produced seven - ten days after culture on maintenance media (Fig. 4D). Callus growth increased dramatically on a fresh weight basis. Cell suspension-derived microcalli for both genotypes were partially desiccated resulting in a very low fresh weight $(2-3 \%)$. Per cent weight gain on a fresh weight basis was calculated ten days after culture. The effects of proline and ABA on callus growth under stress conditions are presented in Table 2. The friable cultures grew fast and increased 10 to 12-fold in fresh weight in a week. Callus growth was much greater when the medium contained $12 \mathrm{mM}$ proline and $50 \mathrm{mM} \mathrm{NaCl}$ followed by $2 \mathrm{mg} / \mathrm{l} \mathrm{ABA}$ without any $\mathrm{NaCl}$ for genotype BR24. Similarly BR26 gained the highest weight in media containing proline followed 
by $\mathrm{ABA}$ in the presence of $50 \mathrm{mM} \mathrm{NaCl}$ (Table 2). The lowest weight gain was recorded for both genotypes in the media containing $100 \mathrm{mM} \mathrm{NaCl}$ and/or 12 $\mathrm{mM}$ proline and $2 \mathrm{mg} / \mathrm{l} \mathrm{ABA}$ (Table 2). There was a significant interaction between genotype and maintenance media indicating that genotypic effect in a particular medium was significantly different from similar or other genotypic effects in some other media. Genotype BR26 performed better in $100 \mathrm{mM} \mathrm{NaCl}$ containing media with ABA (2 mg/l) than BR24 while BR24 performed better in $\mathrm{NaCl}$ containing media with proline $(12 \mathrm{mM})$ supplementation. Proline was found to be essential for the establishment and maintenance of cell suspension cultures in indica rice (Ghosh and Zapata 1993, Rani and Reddy 1996, Giri and Reddy 1998). In the present study indicated that proline had a stimulatory effect on partially desiccated calli for growth, but no noticeable residual effect on regeneration from those calli.

Table 1. The effect of $\mathrm{NaCl}$ in cell suspension maintenance media on the formation of number of micro-calli after four weeks of culturing.

\begin{tabular}{llcc}
\hline Genotype & \multicolumn{2}{c}{$\mathrm{NaCl}$ concentration $(\mathrm{mM})$} \\
\hline \multirow{3}{*}{ BR24 } & 0 & 50 & 100 \\
BR26 & $47.3 \pm 6.35$ & $39.0 \pm 2.08$ & $21.0 \pm 2.08$ \\
& $71.7 \pm 7.26$ & $51.3 \pm 6.77$ & $39.3 \pm 13.83$ \\
\hline
\end{tabular}

Values are mean of three replications \pm SEM. There is no significant interaction between genotype and salt concentration where $p=0.733$ and LSD at $5 \%=23.16$.

Table 2. Effect of proline $(12 \mathrm{mM})$ and ABA $(2 \mathrm{mg} / \mathrm{l})$ on percentage weight gain obtained from partially desiccated cell suspension-derived microcalli of two indica rice genotypes. Values are mean of three replications \pm SEM.

\begin{tabular}{lllllll}
\hline Genotype & \multicolumn{5}{c}{ Cell suspension derived-calli maintenance media } \\
\hline \multirow{3}{*}{ BR24 } & M1 & M2 & M3 & M4 & M5 & M6 \\
\cline { 2 - 7 } & 222.3 & 450.0 & 500.0 & 247.7 & 178.0 & 76.7 \\
BR26 & \pm 28.0 & \pm 28.7 & \pm 57.7 & \pm 54.5 & \pm 19.7 & \pm 14.6 \\
& 216.7 & 201.0 & 366.7 & 366.7 & 107.0 & 105.3 \\
& \pm 16.6 & \pm 10.7 & \pm 44.0 & \pm 33.3 & \pm 9.6 & \pm 7.3 \\
\hline
\end{tabular}

There is a significant interaction between genotype and media where $\mathrm{p}<0.001$ and LSD at 5\% $($ Genotype $\times$ media $)=93.0$. M1, M3 and M5 $=$ MS1 common callus induction media supplemented with $12 \mathrm{mM}$ proline in the presence of 0,50 and $100 \mathrm{mM} \mathrm{NaCl}$. M2, M4 and M6 = MS1 common callus induction media supplemented with $2 \mathrm{mg} / \mathrm{l} \mathrm{ABA}$ in the presence of 0,50 and $100 \mathrm{mM} \mathrm{NaCl}$.

In the present study, like proline, ABA was also more effective on secondary proliferation of cell suspension-derived calli on both saline and non-saline maintenance media in the presence of higher gelling agent ( $0.6 \%$ phytagel).

To induce further development of the somatic embryos in saline and nonsaline conditions, secondary, globular calli were transferred to MS basal solid 
regeneration media supplemented with different concentrations of auxin and cytokinin, with maltose (3\%) as the carbon source and $0.3-0.4 \%$ phytagel as the gelling agent. Four to six weeks after culture, the regeneration capacity and morphogenic responses on different media were observed (Table 3). Cells from suspension cultures of BR24 maintained on media containing $12 \mathrm{mM}$ proline, expressed regeneration potential with a considerable number of green plantlets per culture in media B - 0 (Table 3, Fig. 4E). The same genotype expressed regeneration response in media A - 0 (see materials and methods) when cells from suspension cultures were maintained on media supplemented with $50 \mathrm{mM}$ $\mathrm{NaCl}$ and $12 \mathrm{mM}$ proline. Cells of BR26 maintained on medium containing 12 $\mathrm{mM}$ proline regenerated only on A - 0 media. Cells of both genotypes pre-treated with different salt-stress in maintenance media were unable to regenerate, except cells of BR26 pre-treated on maintenance media with ABA and $100 \mathrm{mM} \mathrm{NaCl}$ which regenerated (12.5\%) although green shoot formation was not remarkable (Table 3).

Table 3. Effect of different regeneration media on the regeneration response of cell suspension-derived calluses pre-treated with partial desiccation treatment following culture on maintenance media designated as M1, M2, M3, M4, M5 and M6.

\begin{tabular}{|c|c|c|c|c|c|}
\hline \multirow[t]{2}{*}{ Genotype } & \multirow[t]{2}{*}{$\begin{array}{c}\text { Maintenance } \\
\text { media } \\
\end{array}$} & \multicolumn{4}{|c|}{$\begin{array}{l}\text { Regeneration } \\
\text { media }\end{array}$} \\
\hline & & A-0 & A-50 & B-0 & B-50 \\
\hline \multirow[t]{6}{*}{ BR24 } & M1 & + & - & $20 \%(6)$ & + \\
\hline & M2 & $t^{*}$ & - & $+^{*}$ & $t^{*}$ \\
\hline & M3 & $10 \%(2)$ & + & $+^{*}$ & - \\
\hline & M4 & - & - & + & - \\
\hline & M5 & - & - & - & + \\
\hline & M6 & $+^{*}$ & - & - & $t^{*}$ \\
\hline \multirow[t]{6}{*}{ BR26 } & M1 & $10 \%(1)$ & - & - & - \\
\hline & M2 & + & - & - & - \\
\hline & M3 & - & - & - & - \\
\hline & M4 & - & - & + & - \\
\hline & M5 & - & - & - & - \\
\hline & M6 & $12.5 \%(2)$ & - & $+^{*}$ & - \\
\hline
\end{tabular}

Parentheses represent the number of green shoots per culture. $+^{*}$ and + : Morphogenic response of green region with or without any root initiation.

The present regeneration study was undertaken mainly on semisolid MS regeneration media using morphogenic micro-calluses/somatic embryos. These morphogenic micro-calluses/somatic embryos were produced on MS semi-solid basal callus induction media supplemented with 1 - 2 mg/l 2,4-D with or without 50 and $100 \mathrm{mM} \mathrm{NaCl}$ from pre-treated cell suspensions in control, 50 and 100 
$\mathrm{mM} \mathrm{NaCl}$ containing MS1 liquid media (Table 2). The basic similarities with other previous reports were using semi-solid MS regeneration media but combination and concentrations of hormones were completely different (a mixture of cytokinins i.e. BAP supplemented with $\mathrm{Kn}$ or 2ip and with auxin NAA) from other reported works (Abe and Futsuhara 1991, Binh et al. 1992, Jain et al. 1996, Rani and Reddy 1996, Valdez et al. 1997, Okamoto 1998). In the present study regeneration capacity was observed only when maltose was used as the carbohydrate source, which supported other reports (Jain et al. 1996, Jain et al. 1997, Rani and Reddy 1996, Pandey and Bhojwani 1999). Increased regeneration was found when calli were maintained on proline-supplemented maintenance media (Table 3) indicating that proline had an indirect effect on plantlet regeneration. on the contrary, a lower level of regeneration capacity was observed from $100 \mathrm{mM} \mathrm{NaCl}$ stressed calli in the presence of ABA (Table 4) suggesting that $\mathrm{ABA}$ is necessary for development of somatic embryos but is inhibitory for their germination.

An attempt was made here to improve plant regeneration efficiency from cell suspension-derived calli by applying partial desiccation followed by indirect desiccation through culturing partially desiccated calli on a medium containing $0.6 \%$ Phytagel. The tissues growing on higher concentration of gelling agent were thus subjected to osmotic stress. It may be assumed that osmotic stress cause disruption of plasmodesmatal connections between pre-embryonic cells, making the cells physiologically isolated and thus allowing a greater number of cells to differentiate. However, it is not clear how osmotic stress effects dramatically enhance the cells/tissues fresh weight. Partial desiccation of cell suspension-derived calli and subsequent maintenance with proline and ABA accelerated somatic embryogenesis by one subculture passage and thus shortened the culture time in tissue.

Results presented in this study demonstrated morphogenic and embryogenic ability in two Bangladeshi indica rice genotypes. Cells of these two genotypes tolerated high osmotic stress induced by $\mathrm{NaCl}(250 \mathrm{mM})$ in suspension cultures. Both genotypes performed lower regeneration (10 - 20\%) response. The poor regeneration response of these two indica rice genotypes can be attributed to the established fact that indica rice varieties are recalcitrant (Hartke and Lorz 1989) and display lower rates of regeneration through suspension culture compared with japonica rice (Valdez et al. 1997). Once regeneration is established multiplication of plantlets can be easily done by in vitro micropropagation system. Plantlets were transferred to a glasshouse under controlled conditions and gave normal spikelet fertility. This work will be continued to produce subsequent generations to assess somaclonal variation for other agronomic characters under either saline or non-saline condition. 


\section{Acknowledgements}

Author is thankful to Dr. D.A. Baker, Emeritus Professor, Plant Physiology, Imperial College at Wye, University of London for his valuable suggestions and advice for doing this work. Author also acknowledges World Bank for providing funds through Bangladesh Rice Research Institute to accomplish this work.

\section{References}

Abe T and Futsuhara Y (1991) Regeneration of rice plants from suspension cultures. In: Biotechnology in Agriculture and Forestry, Vol. 14 Rice. Bajaj Y.P.S. (Ed). pp. 38-46 Springer-Verlag Berlin, Heidelberg.

Bahaji A, Fernando A and Maria-Jesus C (2003) Uptake of an Endocytic Marker by Rice Cells: Variations Related to Osmotic and Saline stress. Plant and Cell Physiology 44: 1100-1111.

Binh DQ and Heszky LE (1990) Restoration of the regeneration potential of long-term culture in rice (Oryza sativa L.) by salt pretreatment. J. Plant Physiol. 136: 336-340.

Binh DQ, Heszky LE, Gyula G and Csillag A (1992) Plant regeneration of NaClpretreated cells from long-term suspension culture of rice (Oryza sativa L.) in high saline conditions. Plant Cell Tiss. and Org. Cult. 29: 75-82.

Ghosh Biswas GC and Zapata FJ (1992) Plant regeneration from long-term cellsuspension cultures of indica rice (Oryza sativa L. CV. IR43). J. Plant Physiol. 139: 523527.

Ghosh Biswas GC and Zapata FJ (1993) High frequency plant regeneration from protoplasts of indica rice (Oryza sativa L) using maltose. J. Plant Physiol. 141: 470-475.

Giri CC and Reddy GM (1998) Production of fertile plants and analysis of protoclones obtained from alginate encapsulated indica rice protoplasts. J. Genet. Breed. 53: 107111.

Hartke S and Lorz H (1989) Somatic embryogenesis and plant regeneration from various indica rice (Oryza sativa L.) genotypes. J. Genet. Breed. 43: 205-214.

Hosseini R and Mulligan b (2002) Application of rice (Oryza sativa L) suspension culture in studying senescence in vitro (I), Single strand preferring nuclease activity. Electron J Biotechnological 5 (on line issue of April 115). Available at http://www. ejb.org/content/vol5/issue/full/8.

Jain RK, Davey M.R, Cocking EC and Wu R (1997) Carbohydrate and osmotic requirements for high frequency plant regeneration from protoplast-derived colonies of indica and japonica varieties. J. Exp. Bot. 48: 751-758.

Jain RK, Jain S and Wu R (1996) Stimulatory effect of water stress on plant regeneration in aromatic indica rice varieties. Plant Cell Rep. 15: 449-454.

Khana HK and Raina SK (1998) Genotype $\times$ culture media interaction effects on regeneration response of three indica cultivars. Plant Cell Tiss. Org. Cult. 52: 145-152.

Kyozuka J, Hayashi Y and Shimamoto K (1987) High frequency plant regeneration from rice protoplasts by novel nurse culture methods. Mol. Gen. Genet. 206: 408-413.

Lee TR, Shultz RW, Bowdoin LH and Thompson WF (2004) Establishment of rapidly proliferating rice cell suspension culture and its characterization by fluorescenceactivated cell sorting analysis. Plant Molecular Biology Reporter 22: 259-267 
Mariani TS, Miyake H and Takeoka Y (2000) Improvement of direct somatic somatic embryogenesis in rice by selecting the optimal developmental stage of explant and applying desiccation treatment. Plant Production Sci. 3: 114-123.

Navraj-Kaur GM, Bharaj TS, Gosal SS, Kaur N and Gill R (1999) Factors enhancing somatic embryogenesis and high frequency plant regeneration in rice. Crop Improvement 26: 23-27.

Okamoto A (1998) An efficient rice cell suspension culture and regeneration of plantlets. Recent Res. Devel. in Fermentation and Bioeng. 1: 109-113.

Ozawa K, Ling DH and Commune A (1996) High frequency somatic embryogenesis from cell suspension derived clusters of cells of an interspecific hybrid of Oryzae. Plant Cell Tiss. Org. Cult. 46: 157-159.

Pandey H and Bhojwani SS (1999) Promotion of androgenesis in rice anther cultures by substitution of sucrose with maltose and mannitol. Biologia Plant 42: 125-128.

Rani TU and Reddy GM (1996) Regeneration of indica rice (Oryza sativa L.) cultivars from embryogenic suspension cultures. Indian J. Exp. Biol. 34: 239-242.

Redway FA, Vasil V, Lu D and Vasil IK (1990) Identification of callus types from longterm maintenance and regeneration from commercial cultivars of wheat (T. aestivum). Theor. Appl. Genet. 22: 609-617.

Tsukahara M, Hirosawa T and Kishine S (1996) Efficient plant regeneration from cell suspension cultures of rice (Oryza sativa L.). J. Plant Physiol. 149: 157-162.

Valdez M, Garra G and Espiona AM (1997) Establishment of morphogenic rice cell suspension cultures (Oryza sativa) in Costa Rica. Rev. Biol. Trop. 45: 593-595.

Widholm JM (1972) The use of fluorescein diacetate and phenosafranine for determining viability of cultured plant cells. Stain Technol. 47: 189-194. 